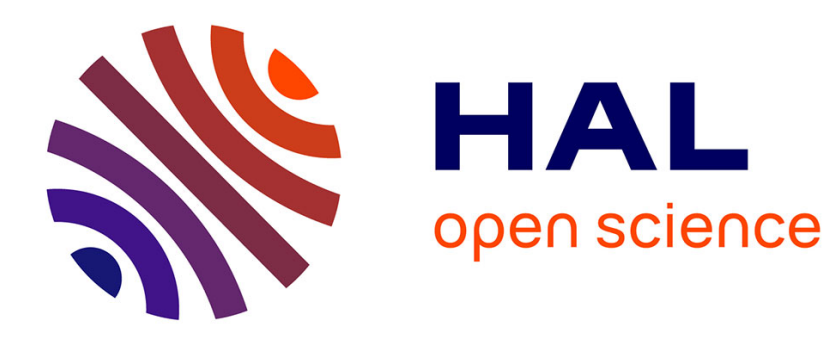

\title{
In the Memorial Room: The Conditions of Being a Writer
}

\author{
Alice Braun
}

\section{To cite this version:}

Alice Braun. In the Memorial Room: The Conditions of Being a Writer. Journal of Postcolonial Writing, 2015, 51 (5), pp.591-602. 10.1080/17449855.2015.1072889 . hal-01640470

\section{HAL Id: hal-01640470 \\ https://hal.parisnanterre.fr/hal-01640470}

Submitted on 6 Dec 2017

HAL is a multi-disciplinary open access archive for the deposit and dissemination of scientific research documents, whether they are published or not. The documents may come from teaching and research institutions in France or abroad, or from public or private research centers.
L'archive ouverte pluridisciplinaire HAL, est destinée au dépôt et à la diffusion de documents scientifiques de niveau recherche, publiés ou non, émanant des établissements d'enseignement et de recherche français ou étrangers, des laboratoires publics ou privés. 
In the Memorial Room: The Conditions of Being a Writer

\section{Alice Braun \\ University Paris Ouest Nanterre la Défense, France}

In the Memorial Room, the second novel by Frame to be published posthumously, announces many of the themes that she would develop only a few years later in Living in the Maniototo, including the role of the artist in her own fiction. The artist figure this time is a young New Zealand man who has been awarded a fellowship giving him the chance to live and write in the same French town where Margaret Rose Hurndell, a national literary figure, spent some time before she died. By staging the gradual erasure of its main protagonist, In the Memorial Room allows us to reflect on the place of the artist in a society obsessed with the cult of celebrity, when being a writer should imply a dissolution of the ego and the foregrounding of language as the main driving force of his/her art. Through the seemingly trivial attention given to the artist's material condition, Frame dramatizes the dialectics of the author's role with regards to his/her creation through the main characters who epitomise the different modalities of being a writer.

Keywords: metafiction, autobiography, romanticism, post-colonialism, death of the author

In the Memorial Room, Janet Frame's thirteenth novel, was published in 2013, almost a decade after her death. Frame wrote the novel in 1974 in the wake of her time spent in Menton, France, on the Katherine Mansfield Memorial Fellowship (also known as the WinnManson Menton Fellowship), which she was awarded that same year. The introduction to the text suggests that Frame wanted the novel to be published posthumously because it painted an unflattering portrait of people who were alive at the time she wrote it, a point made when her first posthumous novel Towards Another Summer was published - in 2007, three years after Frame's death. Several aspects of the narrative warrant an autobiographical reading of the novel: most of the events depicted can be traced back to actual happenings, ${ }^{1}$ and the novel is deeply concerned with the process of writing itself. Harry Gill, a writer in his thirties, has just 
been awarded the Watercress-Armstrong Fellowship and is about to leave for Menton, where according to the terms of the Fellowship, he is to write in the Margaret Rose Hurndell Memorial Room. There, much to his dismay, he discovers the place to be a bare room without basic facilities such as running water or lighting. Similarly, the flat he has been offered to rent is bleak and uncomfortable, adding to Harry's general sense of unease. As he struggles to find more appropriate living arrangements, he finds that his attention is constantly sought by the members of Menton's English-speaking community (some of them New Zealanders, like the Watercresses and the Fosters; others English expatriates, like the Markhams and the Lees), all of whom are obsessed to varying degrees with Margaret Rose Hurndell, the famous late writer who presides over Harry's experience.

A New Zealand writer who died at a young age in France, Hurndell is a thinly disguised version of Katherine Mansfield, the first literary celebrity to have been claimed by New Zealand (although her "New Zealandness" has been contested), ${ }^{2}$ and to whom Frame herself was constantly compared in her life-time. In his interaction with the English community in Menton, Harry finds that his privacy is increasingly encroached upon. In particular, his writing is constantly interrupted by forced socialising and the need to find more suitable accommodation. Moreover, after he is befriended and finally taken up by the Fosters, Margaret Rose Hurndell's own sister and brother-in-law, and allowed to use a studio in their villa, Harry discovers that his hosts are in fact having alteration works undertaken in his studio, endangering the quiet of his "sanctuary". In Frame's work, the house is a powerful symbol of identity, but it is also a place to which the artist can retreat to be alone with her work (Braun, 2007). Yet it seems that nowhere in Menton is Harry able to find a place where he can concentrate on his writing. Similarly, Harry's position as the beneficiary of the Watercress-Armstrong Fellowship is undermined by the Watercresses themselves, who 
believe that their own son Michael would make a far better Fellow than Harry. As a result, Harry, who describes himself as "a dull personality, almost humdrum, a plodder from day to day with an occasional glimpse of light" (Frame 2013, 4), starts wondering if he is not a usurper, and if Michael Watercress, the "stereotype author" (34), is not the real Fellow and, more disturbingly, the truer writer of the two. Small talk, human interactions and alteration work all become part of the background noise that interrupts Harry's creative flow. While he had been convinced for years that he was going blind - and was fascinated by the drama of it - Harry discovers at the end of the novel that he has become completely deaf instead, and his speaking voice dissolves into a stream of correspondence-style clichés. At the end of the narrative, it becomes clear that, as part of the exploratory path that Harry has been following, he has managed to get rid of the different models of authorship under the spell of which he had been under, in order to espouse a more postmodern representation of the author as a mere channel for language.

In the Memorial Room can be read as a blueprint for Living in the Maniototo, which was published in 1979, only five years after In the Memorial Room was written. Similar in theme and imagery to its illustrious successor, In the Memorial Room also appears to supply information that was only hinted at in the piece missing from Living in the Maniototo, in which several fictional elements (i.e. the names Watercress and Margaret Rose Hurndell, and the Menton setting) identify it as the novel that the protagonist, Mavis, sets out to write before her attention is commandeered by her four guests:

And where was my novel? I had briefly visited Menton where Margaret Rose Hurndell lived for a time, and I was interested in the 'experts' which surrounded her, her work, and her memory. [...] The Watercress family, the known experts on Margaret Rose Hurndell, clamored for my attention which I was paying them in writing the novel. (Frame [1979] 2006, 128) 
In the Memorial Room is therefore metafictionally embedded in Living in the Maniototo, further reinforcing the deep thematic and formal bonds between the two novels. Both of these are concerned with the author's relationship to his/her own writing and to the rest of the world. Mavis, just like Harry, is being offered a place where she can write, but finds herself besieged by friends of her benefactors, who insist on taking up her attention instead of letting her finish the novel she is supposed to write. Similarly, the focus on Harry's material conditions (and the conflict that this issue creates between his need for isolation and his necessary reliance upon others for the basic needs of everyday life) eventually leads to a deeper reflection on the role of the author within society and within his/her own creation. In the Memorial Room is indeed concerned with the artist's condition(s), namely with his social status and his privileged standing within the relevant community, but also in the physical sense of the word with the many afflictions, diseases and physical frailties that set him apart from the rest of that community. Moreover, although the main character in the novel is a man, he, like Mavis in Living in the Maniototo and her avatars Violet Pansy Proudlock and Alice Thumb is clearly another diffraction of the artist figure within the fiction. In a similar fashion, the figure of the writer in In the Memorial Room is diffused through different characters in the novel: Harry of course, but also the national heritage writer Margaret Rose Hurndell, as well as Michael Watercress, the bearded, Hemingwayesque would-be literary prodigy. Indeed, although Harry is at the centre of the novel's preoccupation with the role of the artist, Margaret Rose Hurndell and Michael Watercress interact with him as dialectical counterpoints.

Another theme explored in In the Memorial Room is that of literary celebrity. Within this context, Margaret Rose Hurndell is a figure of the past, as the myth surrounding her presides over Harry's experience in Menton. Michael Watercress, as the new, up-and-coming 
writer, represents the future, and to Harry's mind, seems only too eager to push Harry to one side, in order to take his place in the spotlight. Although a moderately successful author, Harry is mostly renowned in his own country as a historical novelist, a label which does not have the allure of fame associated with a poet or a novelist. Literary celebrity is a relatively recent phenomenon, and can be traced back to the Romantic period, when the status of the author changed along with changes in the law. While there was a shift from the profession of writer to the legal category of author, it was also a consequence of the emergence of the individual as separate from the group (Bernadet 2001, 13-14). In the works of such authors as Wordsworth, Coleridge or Keats, the poet and his emotions occupied the centre of the writing stage as they became the main source of inspiration for literary creation. As Raymond Williams has shown, the Romantic artist became "a special kind of person" (Williams 1958, 39): no longer a craftsman, this artist belonged to another plane of humanity, and was gifted with quasi-divine qualities. The Romantic ideal of pouring one's sensibility into one's own writing, of engaging directly with the reader's emotions, created the illusion of an artist who could be known, befriended, and even loved, as his/her projected self became a vehicle screen for the reader's fantasies. Gradually, the cultural image of the artist caused them to become associated with a certain form of marginality, which became recognised as the privilege of the gifted.

As old cultural hegemonies started being contested, the value of marginality shifted towards those who had been the victims of colonial oppression. As Graham Huggan has shown, the emergence of postcolonial literature created its own brand of marginal heroes, as part of a process following the same cultural logic. Exoticism, in his view, is an offshoot of Romanticism in that it valorises resistance and difference: "In contemporary cultural theory, marginality is often given a positive value, being seen less as a site of social exclusion or 
deprivation than as a locus of resistance to socially imposed standards and coercive norms" (Huggan 2002, 20). In In the Memorial Room, Frame deconstructs the discourse of heroic marginality as being congruent with the condition of the artist in order to give it another definition. As we will see, writers need to let their ego be pushed to the side in order for their writing to take centre stage. If there is anything Harry Gill resists, it is the stance of resistance itself. A historical writer, he is more concerned with facts than with the sacralised power of imagination. Moreover, one of his main characteristics according to others is his "spinelessness" (Frame 2013, 130). In other words, he is everything but celebrity material, unlike Margaret Rose Hurndell and Michael Watercress, whose past and future auras as literary heroes all but doom Harry as writer to disappearance. Yet what if authors had to allow their selves to disappear as the main condition of becoming an artist? I contend that In the Memorial room deconstructs the discourse built around what an artist should be and paradoxically charts the emergence of a new sort of artist: the disappearing one. The issue of literary celebrity allows Frame to question the status of the artist regarding his own work by showing that the cult of venerating famous authors depends on a deeply parasitic process. It also allows her to reflect on the writer's subject matter via the examination of his relationship with the world. I will show that Harry's position on the representational spectrum is closer to the contemporary, Foucaldian definition of the author as mere function, or an element of discursivity. Yet although he is the novel's main protagonist, Harry should not be construed as a straightforward representative of the author within her own text. This kind of reading, which has been widely practiced by authors such as Patrick Evans, is usually rather risky, in that although she creates characters who may seem close to her, Frame never fully identifies with them. In In the Memorial Room, Frame is ultimately more interested in the process of Harry's 
disappearance, and more generally the disappearance of the author from his own text as well the creative possibilities that this process would enable.

Throughout the novel, Harry is almost making excuses for being such a drab personality, as opposed to the flamboyant Michael Watercress, for example. In truth, he has not completely renounced the myth of the artist as Romantic hero; nor has he renounced one of its most important variants, the suffering hero. From the outset of the narrative, we learn that Harry is obsessed with becoming blind, a condition he deems noble enough for a writer, but that he is instead struck by deafness, which he judges as far less dignified. Being deaf instead of blind feels to him like a major "anticlimax", although he feels better thinking of Beethoven: "How comforting to ally oneself with the great" (Frame 2013, 145). Similarly, in the course of his conversations with the keepers of Margaret Rose Hurndell's legacy, Harry learns that she had a limp, and could not walk without a stick, which can be read as a reference to Mansfield, who used to walk with a stick in the later stages of her illness (123). The constant repetition of such details about Hurndell's life is, as we will see, part of an hysterical fetishizing of the dead writer's memory, and of the Romantic vision of the artist as crippled, maladapted, forever on the margin.

The character of Harry does not escape the edge of Frame's irony, as he is under just as many illusions about the figure of the artist as anyone else. Yet he will gradually shed some of these during his tenure as the Watercress-Armstrong Fellow in Menton. The main reason for this is that in the course of his stay he discovers that being a writer requires not only inspiration, but also the material conditions without which inspiration simply cannot occur. The fact that Harry is offered a fellowship in the name of a dead literary celebrity means that he himself is expected by his patrons to turn into another literary celebrity, and that Margaret Rose Hurndell's inspiration is supposed to be passed on to him, as if they both belonged to the 
same class of individual distinct from the rest of humanity. The same naive, almost animistic reasoning is at work, on the one hand, in the Watercress-Armstrong Foundation's choice to have the Fellowship recipients work in the basement of the house where Hurndell is supposed to have lived and, on the other, in its obsession that Harry must "feel" Hurndell's presence in the room to be able to write his novel (Frame 2013, 49). As Janet Wilson has shown, the anxiety of influence at work here operates on another level: instead of attempting to "feel" Margaret Rose Hurndell's presence, Harry chooses to feel in a way that is similar to hers, in the sense of cultivating the same aesthetic of perception (Wilson 2014). Moreover, this Romantic belief in the spirit of place, and in inspiration as ghost-like in its presence, is defeated by the focus on Harry's material and bodily needs: the room has no electricity or running water, and this is incompatible with the physical needs of writing, which include eating, excreting, and being warm. The insistence on the artist's bodily needs throughout the novel pertains to the deconstruction of the figure of the artist as marginal hero, remote from the necessities of everyday life. Yet it is a discourse that Harry and Frame herself ${ }^{3}$ as apparent in her autobiography, are still struggling to come to terms with.

In the Memorial Room is the first novel in which Frame examines the issue of literary celebrity head-on. By the time Frame travelled to Menton, she already enjoyed budding celebrity: she was the acclaimed author of a number of literary works and had already received several national awards for her fiction. Yet her realistic representation of psychiatric institutions (in Faces in the Water, more particularly) had also garnered much unwanted attention from journalists and scholars - and unhealthy fascination by the public - as the myth developed that she actually suffered from the mental illness of schizophrenia herself (even though this diagnosis would be overturned later on). ${ }^{4}$ Although she consistently avoided public life and limited her interaction with the media as much as possible, she was 
nevertheless aggrieved by contentions made by scholars like Patrick Evans, who insisted on reading her books from a strictly autobiographical perspective, treating them as romans à clef (Evans 1981). As Michael King reports in his biography of Frame, she wrote Evans a letter in which she accused him of being "One of the Porlock people" (King 2000, 419), a reference to the unwanted visitor who interrupts Samuel Taylor Coleridge just as he is dreaming up his poem "Kubla Khan". As we know from her autobiography, Frame was an avid reader of Coleridge's poetry and essays, so this reference is more than proverbial. The person from Porlock interrupts the artist's creative flow, as he intrudes on the artist's reverie, wrecking the poetic vision forever. He is also a figure of the more mundane aspects of everyday life, reminding the poet that the material world needs to be attended to (to borrow from the lexical framework of Living in the Maniototo), running along the deeply Romantic fault-line between the world of art and the rest of the world. As Seamus Perry explains, in the Romantic worldview, "The person from Porlock is a representative of the great world outside the magic circle of art and the artist's consciousness" (Perry 2008, 6).

In some respects, Frame, an admirer of the Romantics, shared this vision of the artist's condition as distinct from the rest of humankind. From that point of view, the artist is condemned to being forever intruded upon by others who cannot but remain alien to the artistic world. Creativity, in turn, is constantly hindered by everyday material necessities, and by the need for affection. Those two basic needs are generally conflated in Frame's fiction in the characters' struggle to keep warm, a symbol for both the need for material objects and for human contact. This need for warmth is usually represented as a hindrance in the author's life, interrupting their creative flow and forcing them to attend to their basic physical needs. In his first apartment, Harry is unable to find warmth: 
At night, I'd put all my clothes on the big double bed and creep under the thin blankets provided with the apartment, resting my head on the long sausage bolster, and listening to my transistor radio, its small white earpiece thrust in my ear. I cursed that I was a bachelor. What a dreary life an author's life is, I thought (Frame 2013, 58).

Ironically, the Fosters, who then let him stay in their far more comfortable studio, precisely to make sure that he is warm enough start the alteration work that will send him off the edge. As he is driven into a corner of the apartment to escape the noise of the work, Harry reflects on the constant interruptions the artist has to suffer:

I have observed this attitude towards people who write or paint or compose or in any way desert the living and the visible world to create a world of their own that is a threat to the existence and survival of the generally known world. I have known people to use all kinds of delaying tactics [...], -Don't write today. Come and visit us. Let's talk. Let's drink. Let's make love. You don't really want to work today, do you? Don't desert us, don't threaten us, stay here with us, safe in the known world, looking at the sky and the sunlight, relaxing, after all, you're a long time dead. (Frame 2013, 138)

Here, Frame adds a twist to the paradigmatic division between the tangible world and the realm of the imaginary by suggesting that the artist may be just as afraid of leaving "the generally known world" as anybody else.

These constant interruptions are the price to be paid for artists' dependence on their patrons. As such, the writer in Frame's novel is in the position of the parasite who, as Michel Serres describes in Le parasite, eats at the table of others and is only able to repay the courtesy of his/her hosts by telling them stories. Yet the positions of host and parasite are profoundly interchangeable, and Harry's hosts quickly turn out to be true parasites, feeding off the artist's aura, basking in the derivative glory of being "a relative of the famous" as sister or friend of the dead writer Margaret Rose Hurndell, or parent of the writer-to-be Michael Watercress. As Michel Serres shows in his study, the French word parasite may also 
be translated as "static", as in the droning background noise that interferes with communication. The parasite is a disruptive figure; its relationship with the world is one of interruption, just like the Watercresses, the Fosters, the Markhams and the Lees, who keep interrupting Harry, all the while expressing their desire to be his hosts. The Lees, the English couple who run the English library in Menton, try to lure Harry into their house by making this predatory admission, "We'd love to have you" (Frame 2013, 107), before he turns down the invitation, one in a series of offers from the entire Margaret Rose Hurndell community; each couple then vies with the others in a competition to attract the writer to their home. Yet Harry struggles to remain out of his hosts' grasp, first by asserting his invisibility, and then by becoming deaf, so as to shut himself off from the "static" of meaningless social exchange.

In the novel, deafness is not just a coping mechanism - it is a strategy of resistance, similar to that of a host rejecting a foreign body from its system. This analysis is congruent with the diagnosis made by Harry's doctor, who comes to the following conclusion: "Can't help you. Modern disease. Auditory retaliation. Strategy of war" (Frame, 2013, 151). The idea that the positions of host and guest are reversible is also explored in Living in the Maniototo:

The notion fascinated me because it seemed to suit the mysterious unexpected nature of guests and their relation to hosts, and even after having corrected my mishearing, I still marvel at the idea of the 'guess towel' and at the richness of meaning within the words 'guest' and 'host', with a guest as originally 'host', a stranger, hostis, an enemy, a host as guest, an army, a multitude of men, women, angels; planets, stars; a guest as parasite sheltered by the host, the host as sacrifice and ultimately a blessed food." (Frame [1979] 2006, 153)

Chris Prentice demonstrates in a recent article, using Baudrillard's notion of "seduction", how in her later fiction, Frame uses the very materiality of language in order to break out of binary oppositions and enact innovative dialectics in order to challenge our usual assumptions about the world. For Prentice, binary oppositions are replaced in Frame's later novels, such as 
Living in the Maniototo or The Carpathians, with the "duel" of opposites, which causes them to meet and which creates "an agonistic reciprocity", or a coexistence of contraries. By creating a relationship of reversibility between the positions of host and guest, Frame reveals the ambivalence of the relationship between the two. The parasite may not be the 'freeloading' guest feeding on his/her host's generosity, but may instead find him- or herself fed upon. The status of literary celebrity does not bring the artist out of her marginality and into the magic circle of public attention and commercial success. It paradoxically cannibalises the artist's substance only to leave an empty shell behind.

In In the Memorial Room, Frame analyses the parasitic nature of the obsession with artists and their life narratives that is ingrained in the cult of literary celebrity:

I had a horrifying vision of the Watercress family, and the Fosters, and the Lees, assembled in the Rose Hurndell Memorial Room, feeding on the death of Rose Hurndell, nourishing themselves with the power of permanence which death has and which they so much desire. It was like a pagan ceremony. (Frame 2013, 65)

Unable to create anything of their own, the Watercresses and the other couples subsume their existences under the memory of Margaret Rose Hurndell, as if they could pick up the scraps of her aura and claim it for themselves. As Harry eventually realizes, the process of glorification is akin to a form of living embalmment. The death of an author is always more desirable than his/her life: in death, artists are under control, a portable version of themselves. In life, they escape definition, and will forever defeat the expectations of others, "a living anticlimax" (Frame 2013, 148). Harry also comes to realize the link between his own Romantic obsession with blindness and the cult of literary celebrity:

In a way, by turning to blindness, or being directed towards it, I was following a similar path to those around me whom I was beginning to condemn for both their romantic notions of writers 
living and dead and for their uncontrollable desires to seek shelter and permanence in the dead and the work of the dead. (Frame 2013, 136)

Through the figure of Margaret Rose Hurndell, Janet Frame mocks and denounces both the "memorialisation" of the artist's life and the transformation of her art into "heritage", which relegates the writer's actual work to the background. The obsession over minute details of her life amounts to a form of commodity fetishism. Indeed, Harry finds out that some of Margaret Rose Hurndell's letters were recently sold at Sotheby's for an astonishing sum of money. Here, the name of the celebrity writer has imparted an almost magical value to seemingly insignificant scraps of information, as if her aura could be bought and passed around for enjoyment. As Walter Benjamin has shown, there is a deep link between the commodification of art and the cult of celebrity. The cult of celebrity sucks the life out of the work of art by transforming it into a commodity, depriving it of its immediacy; all the while, the name of the author becomes akin to a brand.

The novel's other writer figure is Michael Watercress, who also threatens to erase Harry. Harry feels undermined by his imagined rival, not because Michael has actually written anything yet, but because in appearance, Michael looks exactly like a writer. Harry and Michael even get mistaken for one another at an official ceremony to welcome the new Watercress-Armstrong Fellow:

Standing near Michael Watercress, the perfectly presentable stereotype of the modern author, you could see if you looked closely, though half the body was out of the photo, a rather stocky young man with glasses and curly hair and a look of what might be frenzied embarrassment on his face. He was holding his hand in a mimicry of the bearded young writer's pose. (Frame 2013, 34)

Here, Harry is literally pushed to the sidelines by the avatar of the writer, in a reversal of the Platonic original/copy dichotomy (Frame 2013, 55). This reversal is reminiscent of the 
mechanism of original/replica reversal which is at work in what is called the "house of fiction" in Living in the Maniototo (Frame 1979, 64). Although Harry is essentially the writer, the rest of the world believes Michael to be the writer, because he has the semblance of one. Michael embodies the shift described by Walter Benjamin in The Work of Art in the Age of Mechanical Reproduction: by dint of calling oneself a writer, anybody can actually become one (Benjamin 1936). As Max tells Harry:

Michael is going to cover [the reading of Margaret Rose Hurndell's works] for his newspaper in England. He's doing so well with his writing. He's not written a book yet, but the discipline will come to him, in time. (Frame 2013, 51)By overvaluing the individual personality of the artist, the cult of celebrity has effected an ontological reversal: an artist is not necessarily someone who has created a work of art, but someone who has the personality of one.

Interestingly, Michael is compared on several occasions to the young Ernest Hemingway, a writer who, even before his death, had achieved tremendous fame based largely on aspects of his life story, both real and fantasized (see Del Gizzo 2010): “- When we were in the East, Grace said, (they had been in the East, and many of their sentences began with 'When we were in the East') - people were talking of him as the young Hemingway" (Frame 2013, 41). The effect of the comparison with Hemingway is two-fold. First, it conjures up another representation of the artist as hero with the journalist-turnedwriter, who endows his/her writing with the prestige of actual experience. Second, it poses the question of the subject matter chosen by the artist. Michael's and his family's perception of him as a writer has to do with his experience of a mysterious, essentialised "East". The capitalisation of the word "East" reveals the overarching stance adopted by Grace and Michael regarding their experience abroad: an experience which is essentially conceived as an encounter with a general sense of foreignness (see Said 2003) taking its roots in the imperial divide between self and other. Michael, then, can be construed as the colonial version of the 
artist as hero, who grounds his writing within his cross-cultural experience. In her 1977 essay entitled "Departures and Returns", Frame examines the question of experience and the injunction to travel in order to "gather material". She contrasts the "writing traveller", who writes "about" a country and its culture, with the "travelling writer", who dissolves his/her being into the experience of foreignness in order to become foreign him-/herself. For her, poets "do not 'take' the pulse of another culture, they become its pulse" (Frame 2011, 60). Michael Watercress can be described as one of those writers who nurture the remains of colonialism by pitting their experiencing selves against the alterity of the foreign culture; this culture is de facto exoticised by their gaze (see Huggan 2002, 9-11).

If Michael can be construed as the archetypal "experiencing" writer, Harry is ambiguously attracted to this brand of creativity as he wonders what to do with his newly acquired deafness:

Here I was, then, newly deafened Mr Anticlimax, feeling like one of the species of writers whom I despised - those, growing in number, who must "experience" so as to feel the experience of being of different race, who will work for a year in an office, live in prison, in a cave, on a desert island, in a monastery, in order to write their "intimate story" of life in these places. (Frame 2013, 156)

By his own admission, Harry is no traveller (Frame 2013, 3): as a historical novelist, his writing is dedicated not to reporting his own experience, but to reestablishing the truth: "Wairau Days was written to correct or bring to full blossoming the half-truths of the story of Wairau" (4). Yet, at the beginning of the novel, Harry feels that it is time for him to embark on a new course of creativity. The rewriting of history, as Wilson Harris has shown, is a horizon that needs to be overcome in order for post-colonial literature to break free of its hegemonic shackles (quoted in Ashcroft, Griffiths and Tiffin 2003, 33-34). Just as Harry's disappearing act is a way to escape the logic of literary celebrity and Romantic heroism, it is also a way for 
him to bring forth a new form of writing and to move away from the logic of author intentionality.

In "Departures and Returns", Frame reflects on the idea that one of the main effects of globalisation in literature is the erasure of the author, which, she says, "leaves them in an international exposure to the skeletal themes of literature" (Frame 2011, 65). Instead of resisting that trend, she instead suggests that writers should let themselves be erased in order for another type of literature to be able to emerge:

Sometimes the writer's answer to this trend has been to go a step ahead, as I think the French writers may have done, and fashion a so called 'new novel', where the writer tries to erase himself from his language, which then, clean as can be, untouched by living human experience, becomes, strangely enough in the 'new' novel, a language of the past in the sense that slumbering etymologies are free to waken and haunt the pages, complaining or rejoicing at their metamorphoses. Here the words, the language itself, and its history, become the heroes and heroines. (Frame 2011, 65)

This reflection of Frame's is reminiscent of Mavis's belief in Living in the Maniototo that "language is all we have for the delicacy and truth of telling, that words are the sole heroes and heroines of fiction" (Frame 1979, 112). The focus is shifted to the words themselves, which are the real agents of literature, before it is shifted to the writer, who indeed must be erased. In In the Memorial Room, the process of Harry's erasure is a gradual one and culminates with the sudden onset of his deafness. Just as Dr Rumor had diagnosed Harry's failing eyesight as a form of "intentional invisibility" (Frame 2013, 60) (in a reversal of the positions of emission and reception), Harry's sudden deafness may be interpreted as the extinction of his own individual voice. From the beginning of the narrative, Harry is forced not only to labour under the weight of Margaret Rose Hurndell's legacy, but also to remain outside Michael Watercress's shadow. In appearance, Harry Gill looks like a pale copy of 
Michael Watercress, who appears to be the Platonic idea of the author: "His appearance was so much his ally. The easily identifiable writer, whereas I had long experience of being ignored because I resembled a clerk, a doctor, a commercial traveller, anything but the accepted idea of a 'writer'” (Frame 2013, 193). By contrast, Harry consistently describes himself in the novel as a nonentity, "a fool, a doormat, someone who is forever imposed upon" (26), "an habitual agreer" (39), similar in aspect to "a waiter, or a schoolteacher or a floorwalker or a farmer" (41) and even as "a man of straw" (139). In the novel, Harry Gill is not represented as a celebrity, but as a dull, grey, boring individual who happens to write books. He has no political opinions or Hemingwayesque travel stories or sexual exploits to brag about. For Dr Rumor, Harry is complicit with those who wish to annihilate him, not only because he is too spineless to resist his own erasure, but precisely because as a writer, he must remain spineless: that is, remain supple and loose, keeping his identity open to the words that he is in charge of writing. For him, as well as for Frame, authors must relinquish their mastery over their own writing and dissolve their ego into a continuum of human experience and voices. In Living in the Maniototo, Mavis makes a similar retreat to within the house of fiction: once her characters enter the fictional stage, she is forced to withdraw to her studio and away from view (Frame 1979, 154). The author is not at the centre of her fiction; she is only a channel for it, and she agrees to become overwhelmed by her creation to the point of complete disappearance. Similarly, in In the Memorial Room, Harry believes that, "In authorship, the author is not the tree scattering his books like leaves; the books are the tree; the author is shed, blown away, dies to make compost for other leaves and other trees" (113).

Michel Foucault observed during the same period, in the wake of Barthes's pronouncement on the death of the author, that a new paradigm had emerged around the figure of the writer in association with authors like Proust, Flaubert or Kafka: that of the 
necessary sacrifice of the author, condemned to be erased by their oeuvre (Foucault 2001, 821). 5 This paradigm, Foucault argues, has presided over the evolution of writing from the late 19th century onwards and has informed the nouveau roman's enactment of the death of the author as erasure of all traces of author intentionality from the author's narratives. Harry, who is experimenting on his own disappearance, makes a brief attempt at nouveau roman writing in chapter 8, with its "unadjectived, unadverbed" (Frame 2013, 81) narrative, reminiscent of the formulaic writing of authors such as Nathalie Sarraute, Michel Butor and Alain Robbe-Grillet. By submitting himself to a rule, the writer aims to let go of an allpowerful stance with regard to his/her own writing, and to expose and dissipate the illusion of author intentionality. Similarly, the writer must, for Frame, retreat to within and disappear within his/her writing, and remain a nonentity, an empty vessel, in order to welcome his/her characters into the empty space that is carved out for them: that is, the empty space inside the writer. The marginality of the author is not heroic but literal: eventually, his/her self needs to be pushed to the sidelines:

Have you sensed the nothingness of my nature, that I am as empty as the carriages of the trains that pass, dusty, used, in the morning sun? A novelist must be that way, I think, and not complain of it, otherwise how shall the characters accommodate themselves in his mind? To this you reply that it is he who must enter the minds of his characters? Certainly, but where shall he house them while he enters their minds, but in those empty used trains that pass and pass forever before his gaze? (Frame 2013, 116)

The image of the empty passing train is another figure of the dissolution of identity which is always on the horizon in Frame's novels, yet never fully achieved. Frame's ideal writer must also be erased in that he/she must escape the constraints of literary celebrity that will turn his/ her life story into a myth and relegate their work to a background detail. 
It would be an oversimplification to believe that Harry Gill is a straightforward autobiographical representation of and a mouthpiece for the author Janet Frame, and the other writer figures in the narrative, mere counterexamples of the ideal artist. Harry Gill, Margaret Rose Hurndell, and Michael Watercress can be read as different modalities of being a writer and as illustrations of the different conundra with which writers can be faced in their careers, caught as they are between the necessities of baring their soul to the demands of fiction while running the risk of becoming their own subject, or even their own memorial. I also believe that this novel, much like Frame's other novels, should not be read as a demonstration of or plea for one conception of the writer over another, but as a stage for the dialectical confrontation of different representations of the author figure. ${ }^{6}$ Harry is neither the ethereal Romantic poet wishing to do away with the mundane altogether, nor the national hero who will expose every aspect of his private life to literary scrutiny for the sake of his country's pride. By letting himself be erased, Harry manages to escape the culturally hegemonic representations of the artist which are the by-products of the cult of literary celebrity. The staged marginality common to the different mainstream representations of the artist in the novel is defeated because it is literalized by Frame, who experiments with the possible removal of the artist's voice within his/her own writing. This experimentation could be deemed paradoxical in the work of a writer who has used so much of her own personal life as material for her writing and who has written three volumes of autobiography. Yet one should not study the works of Janet Frame with a particular agenda in mind, as she is always more interested in asking questions than in answering them. The same focus on extinction is present at the end of the autobiography, as the author pleads to go on writing, but eventually agrees to retreat from the writing of her life story and move back into the world of fiction which is where she really belongs. 


\section{Notes on Contributor}

Alice Braun is a lecturer in English at the university Paris Ouest Nanterre la Défense. She has written her $\mathrm{PhD}$ on the work of Janet Frame under the supervision of Claire Bazin, and is currently working on autobiographical texts by female writers, such as Keri Hulme, Jeanette Winterson, and Doris Lessing. She has recently published an article about Janet Frame's Living in the Maniototo in Commonwealth Essays and Studies and about Keri Hulme's the bone people in the LISA e-review.

Dr. Alice Braun

UFR SSA - Bureau D109

Université Paris Ouest Nanterre la Défense

200, avenue de la République

92001 Nanterre CEDEX

France

Works cited

Ashcroft, Bill, Gareth Griffiths, and Helen Tiffin. 2003. The Empire Writes back: Theory and Practice in Post-Colonial Literatures. London: Routledge.

Barthes, Roland. 1984. "La mort de l'auteur" [The death of the author]. In Le bruissement de la langue [The rustling of language], 61-67. Paris: Seuil.

Benjamin, Walter. (1936) 2008. The work of art in the age of mechanical reproduction. Translated by J.A. Underwood. Harmondsworth: Penguin.

Bernadet, Arnaud. 2001. "Historicité de l'auteur : une catégorie problématique" [The historicity of the author : a problematic category]. In Une histoire de la "fonction- 
auteur" est-elle possible? [Is it possible to draw a history of the "author-function?"], edited by Nicole Jacques-Lefèvre, 13-32. Saint-Etienne: PUSE.

Braun, Alice. 2007. "The Writer at Work: Two Short Stories by Janet Frame." Commonwealth Essays and Studies 30 (1): 93-103.

Brown, Ruth. 2003. "Beyond the Myth: Janet Frame Unframed." Journal of New Zealand Literature 21: 122-139.

Cronin, Jan and Simone Drichel, eds. 2009. Frameworks: Contemporary Criticism on Janet Frame. Amsterdam: Rodopi.

Cronin, Jan. 2014. “'What is't that ails young Harry Gill?': Containers, Contents and Composition in Janet Frame's In the Memorial Room." Commonwealth Essays and Studies 36 (2): 93-102.

Del Gizzo, Suzanne. 2010. “'Glow-in-the-Dark Authors': Hemingway’s Celebrity and Legacy in Under Kilimanjaro." The Hemingway Review 29 (2): 7-27.

Delrez, Marc. 2013. “The Dialectics of Embarrassment in the Posthumous Fiction of Janet Frame.” (Forthcoming).

Evans, Patrick. 1981. "Farthest from the Heart: The Autobiographical Parables of Janet Frame in Special Issue: Modern New Zealand and Australian Fiction." Modern Fiction Studies 27 (1): 31-40.

Foucault, Michel. 2001. “Qu'est-ce qu'un auteur ?” [What is an author ?]. In Michel Foucault, Dits et écrits I, 1945-1975 [Spoken and written documents I, 1945-1975], edited by Daniel Defert and Jean Ewald, 817-849. Paris: Gallimard.

Frame, Janet. 1957. Owls Do Cry. London: Women's Press.

Frame, Janet. 1961. Faces in the Water. London: Women's Press.

Frame, Janet. 1963. The Reservoir: Stories and Sketches. New York: George Braziller. 
Frame, Janet. 1965. The Adaptable Man. New York: George Braziller.

Frame, Janet. (1979) 2006. Living in the Maniototo. Auckland: Random House.

Frame, Janet. 1990. The Complete Autobiography. London: Women's Press.

Frame, Janet. 2007. Towards Another Summer. Auckland: Random House.

Frame, Janet. 2011. Janet Frame in Her Own Words. Ed. Denis Harold et Pamela Gordon. Auckland: Penguin.

Frame, Janet. 2013. In the Memorial Room. Melbourne: Text Publishing Company.

Huggan, Graham. 2002. The Postcolonial Exotic: Marketing the margins. London: Routledge.

King, Michael. 2000. Wrestling with the Angel: A Life of Janet Frame. Auckland: Penguin.

Perry, Seamus. 2008. "Tennyson and the Legacies of Romantic Art." Romanticism 14 (1): $1-12$.

Robinson, Roger and Nelson Wattie, eds. 1998. The Oxford Companion to New Zealand Literature. Auckland: Oxford University Press.

Said, Edward. (1978) 2003. Orientalism. Harmondsworth: Penguin.

Serres, Michel. 1980. Le parasite [The parasite]. Paris: Grasset.

Williams, Raymond. 1958. Culture and Society: 1780-1950. London: Chatto \& Windus.

Wilson, Janet. 2014. “Cultural Wealth and Diaspora Despair: Janet Frame's In the Memorial Room." (Forthcoming).

Endnotes

${ }^{1}$ As documented in King's biography of Frame (King 2000, 380-390).

2 In his entry on Katherine Mansfield in The Oxford Companion to New Zealand Literature, Roger Robinson deems her "at best a qualified national icon in New Zealand" (Robinson and Wattie 1998, 341).

${ }^{3}$ Here, one may recall Frame's autobiography, and her own difficulties at dispelling the myth of the artist as suffering hero (Frame 1990, 78-79, 109, 132).

4 Ruth Brown explains, "The contemporary phenomenon of literary celebrity has reinforced the process begun in 1953-63, whereby the Frame life-story became well-known and the fiction screened within a protective framework of respectful admiration." (Brown 2005, 135). 
5 Michel Foucault shows that up until the end of the $19^{\text {th }}$ century, the author figure was able to reach some form of immortality through his writing, which was represented as closely related to his ego, a unique production of unique self. With writers like Flaubert, Proust or Kafka, whose lives were undermined by their activity as writers, emerged the figure of the artist sacrificing himself for his writing, letting it dissolve his ego. One may only think of Proust, and the representation of his latter years as he was literally consumed by the writing of his masterpiece.

6 Jan Cronin analyses Harry's disappearance in similar terms: "One staging is simply replaced by another. As to what exactly is being staged, there is no stable and developed position here; and this is a reminder of the exploratory nature of Frame's fiction" (Cronin 2014, 11). 